\title{
TRADITIONAL AND
MODERN MEDICINE WORKING \\ TRADITIONAL AND
MODERN MEDICINE WORKING IN TANDEM
}

\author{
Engela Pretorius
}

\begin{abstract}
Summary
Because of the many problems relating to health care delivery in Africa, it is becoming apparent that neither the exclusive/monopolistic nor the tolerant legislative systems should be tolerated any longer. Especially since the Alma Ata Conference held by the WHO/UNICEF there has been growing impetus towards either inclusive/parallel (the beneficial co-existence of traditional and mtodern medical systems), or integrated systems. Although the idea of making traditional and modern medicine work in tandem in a united treatment context has its merits, it is atso plagued by issues such as the nature of the products of an integrated training, resistance by stubborn protagonists of either of the two systems, or that only lip-service is paid to the idea of co-operation. Nevertheless, it is believed that all interest groups - the authorities responsible for health care delivery, the Western-trained health care workers, the traditional healers and the users of these services - stand to gain from such liaison.
\end{abstract}

\section{Opsomming}

Vanweë die talryke probleme ten opsigte van gesondheidsorgdienslewering in Afrika, word dit toenemend duidelik dat nòg die eksklusiewe/monopolistiese, ndg die tolerante wetgewende sisteme langer alhier geduld kan word. Dit is veral sedert die Alma Ata-konferensie van die WGO/UNICEF dat 'n dringende aandrif in die rigting van of inklusiewe/parallelle (die heilsame naasbestaan van tradisionele en moderne mediese sisteme) of geïntegreerde sisteme merkbaar is. Ongeag die meriete van skakeling tussen tradisionele en moderne medisyne, bestaan daar sekere kwelvrae rondom sake soos die twyfelagtige produkte van 'n geïnegreerde opleiding, weerstand deur hardkoppige voorstanders van elk van die twee sisteme, of dat aan die gedagte van skakeling slegs lippediens bewys word. Desnieteenstaande word aanvaar dat alle belangegroepe - die owerhede verantwoordelik vir gesondheidsorgvoorsiening, die Westers-opgeleide gesondheidsorgwerkers, die tradisionele helers, asook die gebruikers van hierdie dienste - by sodanige skakeling kan baat.

\section{INTRODUCTION}

Traditional medicine is an ever present reality in both rural and urban societies and recognition of the fact that traditional healers constitute the main source of health care in the developing world has been long overdue. One reason for this is the naive presumption made by development planners that traditional healers would disappear as modern medical care became available. Despite the introduction of modern medicine by the colonial powers, inhabitants of Africa have never stopped utilising traditional medicine. With the advent of independence in the sixties Africans felt the need to rediscover their socio-cultural identity and traditional medicine, being an integral part of their cultural heritage, benefited from this. In addition economic circumstances after independence were such that imported techniques and medicines became less accessible to Africans. This situation forced the authorities to approach the problem from another angle by exploring the possible utilisation of indigenous sources, thereby establishing a new syncretic national health care delivery system.

The aim of this article is to probe the possibilities, merits and demerits of traditional and modern medicine working in tanuem.

\section{A MACRO PERSPECTIVE ON TRADITIONAL MEDICINE: LEGISLATIVE APPROACIIES}

The numerous legislative approaches to traditional medicine fall into four broad categories:- exclusive systems, tol t systems, inclusive systems and integrated systems (Stepan 1983:292-308).

The Exclusive (Monopolistic) Systems In these systems only the practice of modem medicine is regarded as legal, while all other forms of healing are excluded. Within this category several pattems are distinguishable of which the following two perhaps are the most important:- a strict, total and enforced monopoly, and the socialist model. The former is to be found in the United States of America, France and Belgium, as well as in French and Belgian colonies in Africa, where legislation to this effect remained operative, at least in theory, after independence. The health care system found in Russia and the East-European Socialist countries is characterised by the exclusiveness of modern health care provided by the state. Those developing countries which opted for a socialist system accordingly displayed a cautious, even slightly negative attitude towards certain aspects of traditional medicine.

\section{The Tolerant Systems}

A tolerant system amounts to a laissez-faire policy. In this case only the system based on allopathic medicine is recognised, while the existence and significance of the traditional sector virtually is ignored. Examples of such tolerant systems are to be found in the German Federal Republic, the United Kingdom and the Republic of South Africa. The tendency in Commonwealth countries to be more liberal in recognising traditional healers must be viewed in the light of the fact that former British colonial policy aimed at minimal interference with indigenous practices. In South Africa, the Council of Associated Health Professions, a statutory body not affiliated with the Medical and Dental Council, makes provision for the registration and control of traditional healers.

The Inclusive (Parallel) Systems

In these systems, traditions other than allopathic medicine are recognised legally, so that two or more systems of health care co-exist. In order to be eligible for such organisational inclusion, the particular traditional system has to be highly formalised; this implies that such a medical system must possess medical traditions, literature and teaching systems which can be 
studied and continued. Such systems arc not to be found in Africa, but may be found in parts of Southern Asia such as India.

\section{Integrated Systems}

In this case modern and traditional medicine are united in terms of medical training and jointly practised in a unique health care system. The integrated training of health practitioners is official policy. At the present time it appears that integrated systems are to be found only in China and Nepal.

\section{A MICRO PERSPECTIVE ON TRADITIONAL MEDICINE}

\section{Utilisation Patterns}

While policy makers with the aid of international bodies such as the World Health Organisation (WHO) only recently have begun contemplating the co-ordination and integration of traditional and modern medicine, the public have been utilising both without any problems for a very long time.

sation patterns are established by persons thuving from one sector of a health care system to another in search of diagnosis, healing or other medical services. A pattern is simultaneous when a patient consults different sectors concurrently. It is sequential when a patient exhausts the resources of one sector before going to the next. A utilisation pattern also may be interchangeable in that certain conditions/illnesses are taken for treatment to one sector, while the other sector is utilised in the case of other conditions/illnesses. The utilisation of Western medical services by non-Westerners does not mean that their own traditional ideas are abandoned. According to Foster and Anderson (in Jansen 1983:14) "... traditional peoples show great ingenuity in reconciling scientific medical practices with their own etiological systems".

The phenomenon of dual utilisation of medical resources is significant because it provides a basis for attempts at liaison between modern and traditional medicine. With this in mind and inst the background of the different hyslative approaches, we can turn now to the ways in which traditional medicine can be made relevant in primary heal th care.

\section{LIAISON BETWEEN \\ TRADITIONAL AND MODERN MEDICINE}

Though space does not allow discussion of the many problems relating to health care delivery in Africa, it may be stated because of these problems, it is bccoming apparent that neither the exclusive (monopolistic) nor the tolerant lcgislative systems can be accommodated here any longer. Especially since the Alma Ata Conference held by the WHO/UNICEF (United Nations Children's Emergency Fund) in 1978, there has been a growing impetus towards either inclusive (parallel) or integrated systems. The former option comprises the legitimising of traditional medicine which could facilitate the beneficial co-existence of the two medical systems. The second option which is the integration of the two systems, has been advocated by the WHO. According to this organisation the two medical systems share sufficient commonality to facilitate integration.
The way in which the two systems correspond is evident from the collective, community-orientated activities of traditional medicine and the community-orientated primary health care programmes of modern medicine: "From the former there come health precepts such as balance, rhythm, coolness, purity, and plenitude. and from the latter essential prerequisites of these states such as adequate and clean water, infant care, sewage facilities, adequate nutrition, and good housing, all organized within local communities" (Janzen in Green 1988:1126).

With a view to conceptualising the conditions for liaison between the two medical systems, the following analogical model may be used: the following two ways, viz. complementarity or integration.

\section{COMPLEMENTARITY/ CO-OPERATION}

When this relationship exists, traditional and modern medicine co-exist as two independent sectors, each respecting the uniqueness of the other. Co-operation is a multi-faceted process, including aspectssuch as mutual referral (Yoder 1982), the professionalisation of traditional medicine (Staugard 1986) and intercalation (Yoder 1982)

\section{Mutual referral}

In order to effect co-operation between traditional and modern medical practitioners by means of a system of mutual referral, it is imperative that both types of healers take part in

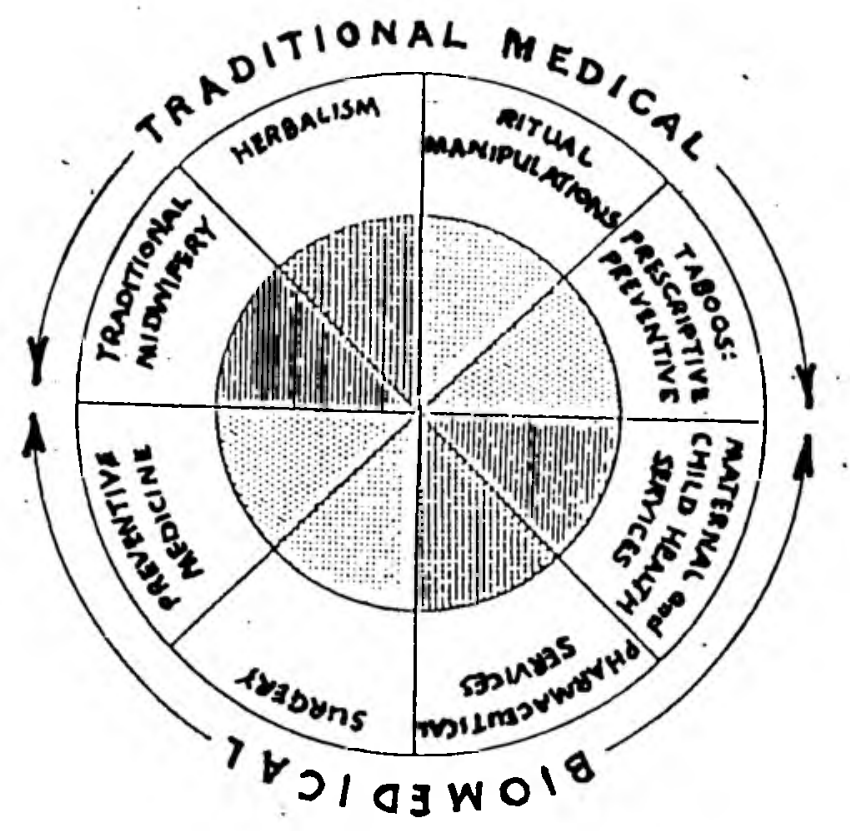

some basic training pertaining to the "alternative" type of care. This will enable them to refer patients to the "alternative" when appropriate. In addition this process will have the advantage that practitioners could incorporate some of the ideas and practices employed by their counterparts, thus improving their own practice. The main purpose of co-operation through a system of mutual referral however, should be the improvement of quality care to patients, and according to Yoder (1982:1856) "[it] should not be undertaken merely to increase the understanding of practitioners of the 'alternatives' available or to serve as a stop-gap measure until biomedical care can be expanded."

Professionalisation of traditional medicine This is the institutionalisation of more standardised, empirically-based training of traditional healers, the adoption of aspects Western medicine and especially the
In order to create a new type of national medicine can be made relevant in either of 
establishment of traditional healers associations. For some this process is an unacceptable option for any $c^{0}$-operation action because such professionalisation implies control and regulation of the activities of these healers by the authorities (MacCormack 1986:153; Staugard 1986:68). This process also could alienate the traditional healer socially and culturally from his local community as well as running the risk of forcing the traditional healer to concentrate on those elements of traditional medicine such as herbalism, which can be accommodated within the framework of modern medical thinking.

Because traditional medicine is dominated by preventive activities, professionalisation could result in the curative- biased methods of the modern health care sector being transferred to the traditional sector. Bringing together traditional healers within associations could also be one of many tactics to exclude them from primary health care training. A contrasting point of view is that inclusion of traditional healers in associations constitutes the only means of obtaining any say in health matters at the national level and thus real political power in society (Green 1988:1127).

\section{Interculation}

When local non-modern medical traditions possess medicines of equal efficacy as drugs used in the modern sector, a kind of co-operation is possible whereby traditional medicines are intercalated into the armamentarium of the official medical sector. Intercalation is therefore the adoption of materia medica from the medical sector, not because they are more beneficial than similar drugs/medicines already existing in the pharmacopoeia of modern medicine (eg. rauwolfia), but because they correspond to these drugs. Intercalation of drugs could have an economic advantage in that fewer drugs need to be imported, leaving more funds which could be utilised towards the expansion of services.

\section{INTEGRATION}

Integration refers to the utilisation of traditional healers in the official medical sector as an inexpensive way to extend the availability of efficient medical services. According to Pillsbury (1982:1826), this entails the recruiting of traditional healers into a newly established scheme of community heal th care workers, and training them in a new repertory of tasks. This already has materialised in the successful integration of traditional midwives into the official medical sector in various countries.

\section{ADVANTAGES OF LIAISON IBETWEEN TRADIONAL AND MOIDERN MEDICINE}

For any linking programme to be successful it is imperative that four particular interest groups co-operate, viz. the authorities responsible for health care delivery, the health care workers trained in Westem medicine, the traditional healers and the users of these services.

- Liaison between modern and traditional medicine can be fruitful in health programmes aimed at altering health behaviour or the attitudes of target groups. liaison could improve health care knowledge, benefitting everyonc, especially because of the inherent possibility of extended and more efficient population coverage.

- Apart from avoiding the problem of cultural or technological approaches irrelevant to the user, modem medicine could benefit from liaison when excessive demands on its inadequate supply of health care workers are relieved by the mobilization of indigenous health care resources

- The users stand to gain most from such a venture. Accessibility, as well as the appropriateness of health care could improve substantially, while appropriate referrals in the case of serious or extraordinary conditions will become possible.

- Traditional healers being a mixed group with no standardised training and therefore no legal standing could benefit from liaison by augmenting their skills and knowledge, whether simply by contact with or by actual training in biomedical procedures. Additional skills could generate increased income.

\section{PRORLEMS PERTAINING TO TIIE SUCCESSFUL LINKING OF MODERN AND TRADITIONAL MEDICINE}

The idea of making traditional and modem medicine work in tandem in a united treatment context, has its merits. Yet it is also plagued by issues such as the unfamiliar products of an integrated training, resistance by stubborn protagonists of either of the two systems or the possibility that only lip-service is paid to the idea of co-operation.

Despite the demise of colonialism in Africa and the revival of African socio-cultural identity "ritualistic" admiration of Western culture still endures. Although African regimes have declared their willingness to accept and improve traditional medicine, this has not been incorporated into legislation. By 1983 only four of the $\mathbf{2 5}$ countries in the African sub-region for which data are available had passed legislation in this regard (Ramanohisoa 1983:213-214).

The different views regarding illness etiology, treatment methods, religious principles, morbidity and mortality held by the various functionaries of the two medical systems, constitute fundamental obstacles in the way of that necessary mutual understanding and recognition which could lead eventually to legitimising the traditional medical system. This slate of affairs has implications for standardisation of the medicines and practices of traditional healers. Because of the fact that traditional medicine is governed by secrecy, these healers would be hesitant to divulge much information. Even if secrecy does not prove to be particularly problematic, standardisation of traditional medicines could be because of the considerable variation in the recipes of traditional healers. In addition to this, even the biomedically acceptable part of traditional medicines and practices could be based on the supematural, making it unacoeptable to those working in the modem medical sector

The aforesaid would imply the demystification of the traditional healing role in order to bc incorporated meaningfully into a national heal th care system. This strategy however, contains certain negative aspects which cannot be denied. Demystification without careful reflection could make utilisation of traditional healers futile, and could even act as "... a kiss of death" (Staugard 1986:67), if, according to Rappaport (1980:92), "... the props upon which his image rests have been neutralized or destroyed".

\section{CONCLUSION}

Opponents of traditional and modern medicine working in landem, who are usually representatives of the conventional medical establishment, generally make much of the problems concerning the well-known potentially harmful effects of iraditional medical practices. Others point to the immense cost involved in the testing and certifying $g^{\text {sw }}$ be efficacy of medicines, as well as the lice $g$ and monitoring of practitioners. Contrary 10 these sentiments, the WHO (1978:18) regards the synthesis of traditional and modern medicine as the best possible way to realise the universally soughi-after aim of "health for all by the year $2000^{\circ}$. The African medical care blanket appears to be too small to cover the health care needs of all its inhabitants. Even if traditional and modern medicine seem to be strange bed-fellows, everything points not only to the possibility of liaising, but also to an imperative in this regard. For Elling (1981:90) "... [ I] he question is not whether there will be accommodation with or development of and mergers with traditional approaches in much of the world; the question is how this will be done and what it will mean"

\section{Acknowledgements}

Acknowledgement is hereby given to the Human Sciences Research Council (programme Affordable Social Security) and the Institute for Research Development for financial supp

\section{REFERENCES}

ADEMUWAGUN $Z$ A, AYOADE J A A IIARRISON I E \& WARREN D M (eds). 1979. African Therapeutic Systems. Waltham, Massachusetts: Crossroad Press.

ASUNI T. 1979. Modern medicine and traditional medicine. In: Ademuwagun $\mathrm{ZA}$ et al. 1979:176-181.

BANNERMAN R II, BURTON J \& WEN-CHIEH C (eds). 1983. Traditional medicine and health care coverage: a reader for health administrators and practitioners. Geneva: World Health Organization

ELLING R II. 1981. Political economy, cultural hegemony, and mixes of traditional and modem medicine. Social Science and Medicine 15A:89-99.

GREEN E C. 1988. Can collaborative programs between biomedical and 
indigenous health practitioners succeed? Social Science and Medicine 27(11):1125-1130

GREEN E C \& MAKIIUBU L. 1984. Traditional healers in Swaziland: toward improved co-operation between the traditional and modern health sectors. Social Science and Medicine 18(12):1071-1079.

JANSEN F E. 1983. The medical system as an aspect of culture and some acculturative effects of Western cross-cultural medical services. South African Journal of Ethnology 6(1):11-17.

LAST M \& CHAVUNDUKA G L (eds). 1986. The professionalisation of African medicine. Manchester: Manchester Universily Press.

MaCCORMACK C. 1986. The articulation of Western and traditional systems of health are. In: Last $M$ and Chavunduka $G$ L, 986:151-162.

NEUMANN A K \& LAURO P. 1982. Ethnomedicine and biomedicine linking. Social Science and Medicine 16:1817-1824.

PEARCE T O. 1982. Integrating Western orthodox and indigenous medicine: professional interests and attitudes among university-trained Nigcrian physicians. Social Science and Medicine 16:1611-1617.

PILLSBURY B I. K. 1982. Policy and evaluation perspectives on traditional health practitioners in national health carc systems. Social Science and Medicine 16:1825-1834.

PRETORIUS E. 1990. Die rol en benutring van tradisionele helers in 'n swart woongebied by Bloemfontein. Unpublished D.Phil. dissertation, University of the Orange Free State, Blocmfontein.

RAMANOHISOA C. 1983. The African Region. In: Bannerman $\mathrm{K} H$ et al. 1983:209-221.

RAPPAPORT H. 1980. The integration of scientific and traditional healing: the problem of de-mystification. Ulin P R \& Segall M H, 1980:81-98.

SPRING A. 1980. Traditional and biomedical heal th care systems in Northwest Zambia: a case study of the Luvale. In: Ulin P R \& Segall M H, 1980:58-79.

STAUGARD F. 1986. Traditional health care in Botswana. In: Last $\mathrm{M}$ \& Chavunduka $\mathrm{G}$ L, 1986:51-86.
STEPAN J. 1983. Legal Aspects. In: Bannerman R H et al., 1983:290-313.

UL.IN P R \& SEGALL M H (eds). 1980 Traditional health care delivery in contemporary Africa. Syracusc University, New York: Maxwell School of Citizenship and Public Affairs.

WORLD HEALTH ORGANIZATION. 1978. The promotion and development of traditional medicine. Technical Report Scries 622. Geneva: WHO

YODER P S. 1982. Biomedical and ethnomedical practice in rural Zaire: contrasts and complements. Social Science and Medicine 16:1851-1857.

YOUNG A. 1983. The relevance of traditional medical cultures to modern primary health care. Social Science and Medicine 17(16):1205-1211.

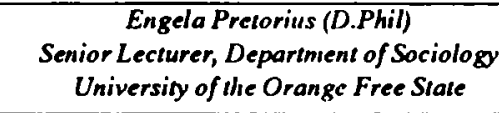

